\title{
Application of Cooperative Learning Theory in Comprehensive English Course Teaching
}

\author{
Zhang Ying \\ Foreign Language Department, Jining University, Qufu, Shandong 273155, China
}

Keywords: cooperative Learning; comprehensive English skills; cultivation

\begin{abstract}
The teaching effect of comprehensive English courses has a significant influence on basic language skills of students of English major. How to cultivate and improve students' comprehensive application ability and give full play to the advantages of comprehensive English courses is important for college English teaching and is a problem in urgent need of solution at present. The teaching strategy of cooperative learning centers around students, attaches importance to the cooperation between teachers and students, gives full play to students' autonomy and initiative, stresses positive mutual support and cooperation between students, pays attention to giving play to each student's enthusiasm, cultivates students' leading role, independent learning ability and team cooperation spirit, provides opportunities for students of different levels to actively participate in learning and experience success, promotes communication and exchange between students, deeply exploits individual potentials, and meets their learning needs, so as to achieve the requirements for cultivation of students' comprehensive English skills as provided in the teaching syllabus for English major in colleges and universities.
\end{abstract}

Comprehensive English course teaching is a basic course for students of English major, and is a comprehensive course and a practical course, by which students will get comprehensive training of skills such as listening, speaking, reading, writing and translating, in this course, in order to gain necessary basic language knowledge. Through the teaching practice in recent years, it is feasible to introduce the cooperative learning theory into the comprehensive English classroom teaching. It can effectively realize changes of the teaching ideas from the teacher-centered classroom teaching mode to the student-centered and teacher-guided classroom teaching mode, and from the teacher-"inculcated" learning mode to the students' independent learning mode, so as to promote the reform of teaching methods.

\section{Cooperative learning theory.}

Cooperative learning theory emerged in the United States in the early 1970s, was put forward by American educationalists Robert E. Salvin, David W. Johnson, Cathy N. Davidsondson et al., had substantial progress in the middle of the 1970s to the middle of the 1980s, and has attracted extensive attention due to the significant effects obtained in the aspects of improving the classroom atmosphere, improving student achievements, promoting cultivation of students' quality, etc. China has discussed cooperative learning since the late 1980s and the early 1990s. The cooperative learning is specially mentioned in the Decision of the State Council on Reform and Development of Basic Education to: "encourage cooperative learning, promote mutual communication and common development between students, and promote teaching to benefit teachers as well as students." [1] Guided by the opinions of the national policy making department, many schools generally pay close attention to cooperative learning in curriculum reform, and have accumulated a lot of practical experiences.

Cooperative learning is mainly based on the subjects such as sociology and psychology, has very solid theoretical foundations, such as social interdependence theory, choice theory (formerly known as control theory), classroom instructional technology theory, motivation theory, cohesion theory, developmental theory, cognitive elaboration theory and contact theory. As one of the important theoretical bases thereof, the developmental theory holds the view that appropriate tasks can help 
children master important concepts in interaction. In the interaction and contact with playmates, children's cognitive development and social development will gradually develop. A famous Soviet psychologist Vygotsky (1978) put forward the concept of the "zone of proximal development", namely: the "distance between the 'actual development level' (independently solving problems) and the 'potential development level' (solving problems under the guidance of adults or solving problems together with other classmates having strong abilities)" ${ }^{[2]}$. He thought that the "zone of proximal development" is the most important characteristics of teaching, teaching can cause and promote internal development of children, children can realize this process only in mutual relationship with surrounding people and within the scope of activities together with their playmates, and then it becomes internal wealth of children.

A famous Swiss psychologist Piaget $\mathrm{J}$ believes that knowledge acquisition of social experience (such as language, value, rules, morality and symbolic system) can only be achieved in the interaction with others. Piaget's theory focuses on researches on conservation. A lot of empirical studies have shown that when individuals cooperate in an environment, participants sometimes will have cognitive conflicts, and insufficient inference, if any, will be put forward and corrected. "Support such a viewpoint that interactions between playmates can help nonconservers become conservers" ${ }^{[2]}$. Many researches have shown that when non-conservers are required to complete conservation tasks together with conservers of the same age group, the non-conservers will gradually form and maintain the concept of conservation in this process. If the non-conservers and the conservers holding different views agree on conservation through cooperation, they will get conservation. Therefore, many piagetists believe that schools should provide opportunities for cooperative learning, and help students improve their achievements to complete their learning tasks. Students learn from each other, will be bound to have cognitive conflicts during discussion of problems, will solve insufficient inferences or difficulties, and finally result in complete understanding. Piaget's viewpoint and Vygotsky's viewpoint respectively have their own emphasis and make up for each other. The former is a learning situation where cognitive conflicts are obviously shown, and the latter is a learning situation where cognitive conflicts are not obviously shown and mutual guidance and support are necessary. The two situations usually coexist in the same learning process.

Based on the above theories, cooperative learning emphasizes to organize teaching around learners, pays attention to cultivation of learners' self-guidance, personal development, personality, intrinsic motivation and cooperative consciousness. The learners follow the cooperative principle, and the cooperative parties can obtain useful information to make up for their own information or knowledge deficiency, so as to improve their ability and achievements. The basic ideas of cooperative learning include: 1 . Concept of interaction: the teaching process is an interactive process, and not only is limited to the interaction between teachers and students, but also includes the interaction between teachers, interaction between students interaction and interaction between various dynamic factors of teaching, all of which can promote student learning. 2. Concept of objective: cooperative learning is a goal-oriented activity that attaches importance to achievement of various teaching objectives. Students communicate with each other, argue with each other, teach and learn from each other and make improvement together, thus realizing achievement of the teaching objectives, such as cognition, emotion and interpersonal communication. 3. Concept of teachers and students: teachers are facilitators, participants and partners, and their relationship with students is not "authority- obedience", but "guidance- participation". 4. Concept of form: in the form of teaching, the teaching organization form combining class teaching with group activities is based on collective teaching with cooperative learning group activities as the main form. 5 . Concept of situation: organizing student learning includes three situations: competitiveness, individuality and cooperativeness, all of which are incorporated into the teaching process, are compatible with each other and complement each other. 6. Concept of evaluation: the goal and scale of teaching evaluation is the standard reference evaluation, and the evaluation center is turned from reaching the standard of traditional personal competition to reaching the standard of cooperation.

As will be found from the basic theories and basic ideas of cooperative learning, based on 
analysis from the perspective of either motivation or cognition, the cooperative learning theory can promote the development of students' cognition and language skills, is a superior teaching method, and provides a new teaching practice and exploration for college English teaching at present.

\section{Problems existing in comprehensive English course teaching and analysis thereof}

Comprehensive English course (or known as the intensive reading course or basic English course) is a strongly comprehensive professional required course specially opened for students of English major, holds an important place in the teaching for English major. As the "major course of major course" and "foundation of foundation", the teaching effect of comprehensive English course has great influence on the basic language skills of students of English major. According to the new English Teaching Syllabus for English Major in Institutions of Higher Learning formulated by the Ministry of Education, "basic English is a comprehensive English skills course, and mainly aims to cultivate and improve students' ability to comprehensively use English. Mainly by basic language training and textual interpretation and analysis, this course enables students to gradually increase their discourse reading comprehension ability, understand expressions and characteristics of various English genres, expand their vocabulary, be familiar with commonly used English sentence patterns, and have basic oral and written expression ability. Teachers should encourage students to actively participate in various language communication activities in class, in order to acquire basic communication skills, and meet the requirements for skills, such as listening, speaking, reading, writing and translating, as provided in the new Syllabus." [3] According to the requirements, comprehensive English course teaching must center on students, and focus on cultivation of students' comprehensive English skills. It is a basic course by which students should acquire necessary basic language knowledge, and is a comprehensive course and practical course by which students should get comprehensive training in skills, such as listening, speaking, reading, writing and translating.

Influenced by the traditional teaching methods and concepts, many teachers and students think that this course includes explaining grammar, explaining texts, and learning key words and phrases, etc. Teachers inculcate students with all kinds of cultural knowledge, key grammars and writing techniques mainly by way of giving lessons, but neglect students' initiative. In order to complete teaching tasks within prescribed time, teachers can only find one or two students to have dialogues or make discussions, sometimes or even ignore training listening and speaking skills, and give lessons from the beginning to end. In this way, most of the class time is occupied by teachers' explanations, and it is difficult for students to practically participate in classroom teaching activities. In this teaching mode, teachers strive to give lessons in all respects, and comprehensively inculcate language knowledge, while students passively accept the language knowledge, are busy taking notes, and neither have time to deeply think, nor have opportunities for actively participating in the interaction between teaching and learning and language communication practice activities. This gives rise to an oppressive classroom atmosphere, so that there are fewer opportunities for communication between students and students or between teachers and students, and students have serious dependence on teachers, so that teaching is "time-consuming and inefficient".

At the same time, this one-way communication in class frustrates students' enthusiasm for and activity in learning. Students are not enthusiastic in class, and always complain about learning nothing. Some students even skip classes and say: "it's not interesting to have comprehensive English courses, and it's not as good as learning by reading the textbook by ourselves." This teaching situation is caused by many factors, but the key factor thereof is the teaching method. This teaching method is fundamentally opposite to the "student-centered" contemporary teaching theory. As time passes, students will take it for granted that learning English is to "constantly accumulate language entities group by group, isolatedly learn structures and rules one by one, and turn language learning into mechanical language structure accumulation" ${ }^{[4]}$. Carefully prepared teachers carefully giving lessons explain the important characteristics of a language to students in detail, but ignore training of language skills, so that students are difficult to improve their understanding and expression ability of language, and cannot meet the requirements for cultivation of students' 
comprehensive English skills, as provided in the new Syllabus. Therefore, how to cultivate and improve students' ability to comprehensively use language and give full play to the advantages of comprehensive English courses is important for college English teaching and is a problem in urgent need of solution at present.

\section{Application of cooperative learning in comprehensive English course teaching}

The teaching strategy of cooperative learning advocates the student-centered idea, emphasizes to give full play to students' autonomy and initiative, strengthens mutual support and cooperation between students, attaches importance to giving play to each student's enthusiasm, cultivates students' leading role, independent learning ability and team cooperation spirit, provides opportunities for students of different levels to actively participate in learning and experience success, promotes communication and exchange between students, and deeply exploits students' individual potentials, so as to greatly meet their spontaneous learning needs.

Limited to less class time and other factors, it is difficult to completely achieve the teaching strategy of cooperative learning in the process of classroom teaching. Therefore, teachers can carry out teaching of cooperative learning through classroom teaching and assigning after-class tasks. Cooperative learning in comprehensive English course teaching should include three stages as follows:

\subsection{Organization stage}

In class, teachers must clarify key points and difficulties of learning, explain to students how to help each other and why cooperation is important, provide students with strategies, especially should particularly emphasize how to carry out discussion and debate between students, and give feedback. Teachers shall assign learning tasks (such as assigning teaching activity contents to the whole class), provide knowledge information (e.g., provide students with text contents), organize students to carry out cooperative learning (e.g., help to build and organize learning groups) and guide student group activities.

\subsection{Implementation stage}

Teachers direct students to work in collaboration, clarify the tasks of individuals and groups, and request each student to participate therein and complete respective tasks. In general, each group should consist of 4-5 members.

The group members collect data and information independently according to their respective division of labor, summarize and comprehensively analyze the contents, and summarize the opinions and viewpoints of their own groups. In this stage, the main objective is to train and cultivate students' skills of listening, speaking, reading, writing, translating and the like, and is implemented by organizing various group cooperation activities mainly in the forms as follows:

\subsubsection{Discussion or debate}

Students need to improve their oral expression ability through a lot of exercises. At present, the comprehensive English course is usually arranged in a large class, students do not have enough opportunities and time for individual exercises in class, and cooperative learning creates more language using opportunities for students. Students exchange information and ideas with each other in discussions or debates, and share their experiences. Each student has a chance to speak English because of different tasks in his/her group, has more opportunities for free communication, can show his/her own views without any restraint, overcomes his/her anxiety and nervousness for speaking English in class, improves his/her English speaking quality with the mutual help between group members, enhances his/her confidence, and promotes to improve his/her communication level, which also help to improve the awkward situation that only a few students speak English in class. 


\subsubsection{Role playing}

According to the contents of a text, students make full use of imagination to create dialogues by creating a scenario, and then play their roles. Each student has his/her own role, and participates in it, which helps to give play to his/her initiative, and deepens his/her understanding and mastery of the contents of the text. This cooperation form not only activates the classroom learning atmosphere, but also widens students' learning thinking. In the process of spontaneous participation, students can continuously improve their interests and confidence, and gradually improve their comprehensive language ability.

\subsubsection{Writing exercises}

Each student analyzes and understands the topic of a composition, thinks about the writing angle and writing contents, lists the outline, then reviews each other's outline, and puts forward suggestions for revision. The teacher can select the outline of a group, write it on the blackboard and discuss and analyzes it together with other students. Then, the teacher summarizes the contents, and gives guidance.

The composition may be checked by the teacher in combination with being mutually checked by group members. The teacher checks some randomly selected students' compositions, summarizes the problems therein, and then sends feedback to all students. According to the teacher's guidance, the students will check each other's compositions, and write strongly targeted comments, and then the teacher summarizes the task accomplishment situation. This can not only avoid the problems that teachers fail to carefully check students' homework in time because of much homework, but also provide students with opportunities for learning from each other and referring to each other, and improve their ability to discover problems and solve problems.

\subsubsection{Simulation of giving lessons}

Teachers can irregularly provide students with opportunities for giving lessons in front of the class to stimulate students' independent learning awareness. The teacher first divides students into a few groups according to the contents of the text, each group respectively carefully reads the contents of the text assigned to the group, discuss the contents within the group and divide the work. For example, some students are responsible for simply introducing or summarizing the contents, some students are responsible for explaining specific contents, some students are responsible for summarization, and each student successively gives a lesson in front of the class. Through the teaching activities, each student deepens his/her understanding and mastery of the text contents and language knowledge, trains and exercises his/her comprehensive skills, makes up for the deficiency of communication only within his/her group (for example, some students make discussions or speak English only in their own groups, and are afraid of speaking English in the whole class), which also plays a good role in pre-service training of some students (such as students of normal college or pedagogical major) in their future teaching career to a certain extent.

\subsection{Evaluation and reflection stage}

Teachers should adopt appropriate and fair evaluation methods to check students' task accomplishment situation, use the test methods and evaluation standards that must be able to reflect the group cooperation achievements and contribution of each group member, and can use a method combining self-evaluation of a group, mutual evaluation of groups and teacher evaluation. Teachers can help students to analyze what they have learned, reflect on students' harvests and problems existing in the process of cooperative learning, and put forward constructive suggestions for improvement. Teachers can help each group to establish a record file of their cooperation results for examination and improvement in the future. 


\section{Attention in teaching practice}

\subsection{Teachers' role}

Teachers are organizers and supervisors in the cooperative learning, guide students in cooperative learning activities, help students to independently, voluntarily, positively and happily participate in various activities, actively treat every student, and attach importance to, respect and encourage them, so as to build a positive and sincere relationship between teachers and students.

\subsection{Reasonable grouping}

Teachers divide students into a few groups after considering the factors, such as gender, ability, personality and psychological quality, instead of simply dividing students into groups with 4-5 students in each group, and try to allow group members to complement with each other, so that students do benefit from cooperative learning.

\subsection{Suitable teaching contents}

Teachers should choose the teaching contents that are suitable for cooperative learning, and cannot regard cooperative learning as the "magic bullet" to solve all teaching problems. Since the above activity forms cannot be realized in one class, teachers should reasonably arrange the teaching time to smoothly complete the teaching tasks and enhance students' comprehensive English skills.

\section{Conclusion}

The cooperative learning strategy, discussion or debate, role playing, writing exercises, simulation of giving lessons, etc. are used in comprehensive English course teaching to arouse students' learning interests, improve students' learning motivation, help to give play to the principal role and subjective initiative of students, and cultivate student's comprehensive quality, so as to meet the requirements for cultivation of students' comprehensive English skills, as provided in the new Syllabus.

\section{Acknowledgements}

Fund program: This paper is an industry-university-research cooperation program between universities and enterprises funded by the Department of Higher Education of the Ministry of Education (201701020041); one of the stage achievements of the teaching reform research program funded by Jining University (JX201522).

\section{References}

[1] http://www.edu.cn/20010907/3000665.shtml Decision of the State Council on Reform and Development of Basic Education. Decision [2001] No. 21 of the State Council, May 29, 2001.

[2] Wang Tan. Brief Analysis on the Theoretical Basis of Cooperative Learning [J]. Curriculum, Teaching Material and Method, 2005 (1): 30-35.

[3] Foreign Language Teaching Steering Committee for English Major in Colleges and Universities. English Teaching Syllabus for English Major in Institutions of Higher Learning [Z]. Beijing: Foreign Language Teaching and Research Press; Shanghai: Shanghai Foreign Language Education Press, 2000.

[4] Chen Yan. Application of Cooperative Learning Theory in English Teaching [J] Journal of School of Foreign Languages of, Shandong Normal University, 2003 (3): 2-5.

[5] Wang Tan. On the Basic Concept of Cooperative Learning [J]. Educational Research, 2002 (2): 68-72. 
[6] Xiong Jun. How to Cultivate Students' Comprehensive Skills in Basic English Teaching [J]. English Teaching and Research in Normal Universities, 2005 (3): 29-31.

[7] Ding Jiqun. Cooperative Learning Method: An Effective Method for Improving Students' Oral Expression Ability [J]. Journal of Hubei Radio \& Television University, 2007 (12): 130-131.

[8] Li Qiao. Research on Cooperative Learning and its Application in English Teaching [J]. Curriculum, Teaching Material and Method, 2003 (6) : 38-42.

[9] Song Xuedong. Effective Application of Cooperative Learning Method in Classroom Teaching [J]. Journal of Liaoning Normal University (Social Science Edition), 2001 (4): 55-56.

[10] Huang Lvhuan. Application of Cooperative Learning Theory in College English Teaching [J]. English Teaching and Research in Normal Universities,2010 (2): 19-22. 